\title{
A Stereoscopic Approach to Distinctions of Justice
}

\author{
Papastephanou $\mathbf{M}^{*}$ \\ Department of Education, University of Cyprus, Cyprus
}

*Corresponding author: Marianna Papastephanou, Department of Education, University of Cyprus, PO Box 20537, Nicosia, 1678 Cyprus, Tel: 0035799325183; Email: edmari@ucy.ac.cy

\section{Research article}

Volume 4 Issue 4

Received Date: October 09, 2021

Published Date: October 28, 2021

DOI: $10.23880 /$ phij-16000202

\section{Abstract}

How we use prominent, culturally significant nouns such as "justice" and how we differentiate the value of nouns through adjectives (e.g. "just" institutions) can be politically relevant. As this article shows, this nearly trivial point can be thought through to implications for a new approach to justice that I term "stereoscopic". A stereoscopic outlook on justice places distinctions of justice (e.g. global, social, etc) into a complex relationship of synergy, tension and critical interplay. To introduce the stereoscopic outlook the article connects the ambiguity of "distinction" with operations that distinguish the meaning of justice through adjectives. A heuristic of distinctions is then introduced to illustrate the relevance of "adjective-noun" operations to justice. This heuristic indicates the possibility and benefits of having a stereoscopic approach to justice in mind when we rethink cases that invite considerations of justice across the globe.

Keywords: Critical Theory; Perspective; Cosmopolitanism; Normativity; Stereoscopic justice

\section{Introduction}

Many philosophies ${ }^{1}$ explore situations relevant to the concept of justice and deploy their own conception of it. However, engagement with the question "what is justice?" is often missing from heated exchanges and debates that relate justice to distinct domains of life and action. True, there have been important philosophical, perspectival elaborations on spheres of justice and context-/practicebased justice. Perspectives help us obtain more awareness of nuances and make it easier to focus on (let us say, to "zoomin") contexts where justice reflects a plurality of principles. "Global justice", "reparative justice" or "gendered justice" allow a scholar to adopt a perspective, write about a case that involves justice and join debates without engaging in a complete theory of justice. Perspectives provide focus to important issues and free scholars from having to deal with all issues simultaneously.

But, as it happens with perspective in art, in philosophy too, perspective regulates the visibility of aspects within

1 John Rawls's theory of justice is a paramount example of this venture. a homogenized space and thus lets some aspects remain hidden or partly visible. ${ }^{2}$ When scholars unify their treatment of specific facets of justice they often do so within a larger perspective on justice that exacerbates the visibility problem. Consider, for instance, that, when the larger perspective on justice is the poststructuralist, there is practically no argumentative engagement with, say, Habermas' or Rawls' conception of justice (other than some very rare and en passant, sweeping and dismissive remarks). A similar disengagement from alternative theoretical perspectives - to the point of rendering them invisible - is noticeable in (post) analytic moral perspectives, in liberal perspectives (whose debates typically involve communitarians or other liberals as interlocutors but almost never poststructuralists), etc.

Sometimes, scholars place specific foci into a larger framework, that of a generic justice that imposes a single set of principles supposedly applicable to all situations. As is well-known, this universalism is often charged with abstraction, unhelpful formalism and even Eurocentrism.

2 Since I have discussed the differences of "perspective" and "stereoscopy" elsewhere I will not cover this ground here. See (Papastephanou, 2021). 
That aside, an additional problem with unifying perspectives on justice is that they often use "zooming-out" tactics (such as the reflective equilibrium, for instance) that seek coherence, scrutinize whether the thinker's various ideas are consistent with her overall beliefs and principles of justice and decide which principles are applicable to different issues and how. This zooming-out, however, reproduces the primacy of a principle-based perspective on justice. It overlooks the significance of fractures within the seemingly coherent whole, reasserts the self in the position of the arbiter of justice and hardly makes visible what would challenge the self from the outset, i.e., from a very different perspective or from a neglected or downplayed viewpoint or from a persuasion that the thinking self may have neglected or may have been unfamiliar with. The zooming-out in question protects the subject from contradictions but, even when it allows the addition of new perspectives, it authorizes them on account of how they refine or revise what the self believes, seeking a homeostatic balance between competing principles and the rest of one's judgments about justice. It does not address issues of invisibility that the relationship of judgment to perspective raises. It does not illuminate how the multiple perspectives (e.g., the Critical-Theoretical, the liberal, the postmodern, the posthumanist, etc) on justice relate with one another or could be played off against one another. It overlooks what their synergy and their tensions may reveal. Reflective equilibrium strategies secure the unity of the self as a moral subject without saying much about the interconnectivity of facets of justice (e.g., social, distributive, environmental, cosmopolitan, etc). However, a like silence is noticeable also in anti-universalist, perspectival treatments of justice.

Nonetheless, the "zooming-in" paradigm of separate perspectives which considers generic ("zoomingout") conceptions of justice suspect dominates now in postmodern approaches to justice. To do justice to the metaphilosophical strengths and weaknesses of universalist or perspectival elaborations on justice requires separate, book-length engagement with each theory beyond the limits of this article. But what is relevant here is that, to my knowledge, most contextualizing efforts miss the kind of interconnectivity of faces of justice that I illustrate later as revealed by stereoscopic "zooming-out" operations. For instance, Michael Walzer's Spheres of Justice [1] does not theorize cosmopolitan justice and its complex connection to, say, environmental justice. Jon Elster's Local Justice [2] explanatorily rather than normatively ${ }^{3}$ focuses on justice

3 Elster $(1992,11)$ points out that one of the differences of his book and Michael Walzer's Spheres of Justice is that Walzer's approach to justice is normative. Both, nevertheless deal with distributive, local and social justice rather than with, say, cosmopolitan justice (e.g., see Elster's remark in his 1992, 194) and do not engage in meta-theoretical study of a more diversified conception of justice (such as the stereoscopic that will at individual and institutional levels, thus overlooking: cosmopolitan justice beyond territorially bound institutions; and geo-political diversifications of what counts as meting out international justice. Generally, in political-philosophical literature, also missing is an elaboration on political operations of the noun "justice" and of the adjective "just" that is recruited to determine desirable institutions (e.g., just education). Furthermore, a meta-theoretical exploration of how distinctions of, say, social, global, legal and environmental justice operate and intersect is lacking too.

This article rests on the assumption that awareness of the above lacunae may motivate one to approach justice through a heightened interest in how its multiple facets intersect. ${ }^{4}$ The article explores the possibility of a stereoscopic outlook on justice that accommodates as yet non-theorized metatheoretical sensibilities and sets various distinctions of justice in critical synergy. As I argue later, metaphorizing a generic notion of justice as stereoscopic allows a better view not only of faces and surfaces of justice but also of the interconnectivity of diverse perspectives, dimensions, nuances and circumstances of justice.

After some preliminary remarks, the article (1) mines the rhetorical, disclosing power of the ambiguity that "distinction" has when attached to justice. It does so to increase awareness of how the cultural prominence of justice (as a self-standing noun of no further determinations) is in a complex interplay with specifications of justice (through attributes that narrow it down and apply it to various cases). Then, (2) a heuristic applicable to distinctions of justice and conducive to identifying "adjective-noun"5 political operations is introduced and (3) a stereoscopic notion of justice is proposed.

\section{Some Preliminary Remarks}

This article will introduce a heuristic that indicates how the normativity of a noun is usually qualified and controlled or specified and demarcated. But, before saying more about this heuristic, let me make a remark that seems

preoccupy the present article). Apart from my article being more headon meta-philosophical in engaging with distinctions of justice, my notion of a stereoscopic justice deals, as will become evident later on, with many more dimensions of justice than, say, currently popular ones such as the distributive, the social and the transitional. And it assumes a more critical attitude toward "zooming-in" operations, that is, entirely context-focused and context-dependent explorations of justice.

4 This assumption along with the assumption that justice needs to be rethought will be justified by the article's arguments as a whole.

5 Though adjectives, especially normative ones, have philosophically been explored as to whether they are attributive or predicative (see, for instance, Rind and Tillinghast, 2008), this distinction would add needless intricacy to this article. Hence I leave it aside, using attribute, predicate and adjective interchangeably. 
bizarre as much as it seems self-evident: our political life, our education, our dialogues, private and public, our hopes and worries, all operate with prominent, normativized and exalted nouns. This remark is self-evident, perhaps trite, since it merely affirms that we are semiotic beings and, in our semiotic universe, some concepts, some signifiers, are valued and serve political purposes (see, e.g., Lotman 2013) [3]. Valorized nouns designate what we are prepared to authorize or tolerate as acceptable power distribution, what we desire as our collective condition of living, what we praise or fear, what should be elevated to our common ideal and what should be monitored, kept in check, sanitized or discarded. Still, the remark seems odd, because, in a politicalphilosophical article, it may be somewhat unexpected to turn one's attention to the noun; for, the noun seems, at first sight, to be a grammatical and syntactic, thus apolitical, term.

Yet, I argue precisely that a turn to the noun and to discursive operations that determine its political scope may be helpful to think justice, just societies, and just institutions (e.g. education) differently and to consider such rethinking necessary. The heuristic will illustrate how the many "faces" of justice revealed through related distinctions of justice intersect with political operations that influence how we think about justice. This invites a response to the question "what faces of justice are revealed through related distinctions in philosophy, humanities and social sciences"? Because this question is too broad for section-length tackling, ${ }^{6}$ my answer here is inevitably skeletal and it is given so that the reader may keep it in view, since my argument presupposes it while going beyond it. My answer then is: at times, justice stands alone in a title/text/project (let us call this justice "self-standing"), with no immediate determinations and distinctions of its domain of application (e.g., institutions, historico-political pending issues, discourses), tools of implementation (e.g., law, redistribution of wealth, reforms) or rightful beneficiaries (the disadvantaged, the wronged, the environment, animals, etc). This "face" of justice has hazy contours and becomes visible through "zooming-out" tactics. The generic concept of justice operates in a somewhat abstract and elastic way. Its meaning is felt as more or less shared and sharable by authors and readers. Butjustice is also used in distinct forms, visible through "zooming-in" tactics. It has faces of more defined features and contours (e.g., the legal face of justice), since kinds of justice are distinguished and, depending on the emphasis being on tools or recipients or domains of justice, relevance is narrowed down to:

- Laws regulating and coordinating action (this can be associated with legal justice).

- Persons having reasonable expectations from others (adjectives pertinent to this facet of justice may be

6 I answer this question in relation to philosophy of education elsewhere. See (Papastephanou, 2021). "relational", "interpersonal", etc).

- Subjects requesting fair treatment by institutions/states (individual justice).

- Groups meriting rights, voice, material aid, remedial policies, a fair share of wealth, and access to power (justice as "social”, "distributive", "political”, etc).

- Nature and non-human beings viewed nonanthropocentrically (environmental/posthumanist justice).

- Neglected ideas clamoring for deserved attention (discursive justice).

- Localities inviting special or urgent collective action and measures (justice as "international", "global" or "cosmopolitan").

- Political configurations passing from autarchic pasts to democratic futures (transitional justice).

- Temporalities compelling the anamorphic gaze ${ }^{7}$ that enables acknowledgement of past ethico-political debts or cross-generational responsibility to futurity (restorative, reparative justice).

The distinct normativities sampled above indicate multiple faces/facets of justice that identify diverse foci and standards of just action and involve respectively different justificatory grounds of those standards. This article argues that it is not enough to merely differentiate these faces and discern their perspectives. We also need to study their conceptual and political interconnectivity in ways that allow a more stereoscopic vision of simultaneous co-operations, synergies or tensions of distinctions of justice.

Attention to how signifiers perform normative tasks and are invested with political operationality is not new. Critical discussions of normativity [4] and crypto-normativity [5] and thinkers as diverse as Judith Butler, Karl-Otto Apel, Maeve Cooke, Michel Foucault and Ernesto Laclau have explored normative terms and claims, albeit in drastically different ways. Special attention has attracted the conception of a signifier whose established meaning is contested by all social groups. Antagonistic social forces engage with a valued signifier, empty it from well-worn contents and aspire to fill the void with a new promise. Justice is such an exalted signifier for theory and research projects. But my issue here is not the noun as ethical void in agonistic philosophies. As explained above, I wish to explore how a grammatical-syntactic operation, that of determining exalted nouns through adjectives, is deep down a political operation of significance for scholarly and research engagements with justice.

We often use "justice" as a self-standing noun but we also qualify it through adjectives and distinctions that make

7 On this, see Papastephanou 2017a. 
it at times Janus-faced and more frequently multi-faceted. All these face(t)s correspond to distinct normativities, as they diversify the general normativity of the noun "justice" by making its contour less hazy through related adjectives (e.g., legal, social, global, etc). Various such faces of justice are typically employed in political philosophy separately from one another, nested as they are in diverse perspectives. $20^{\text {th }}$ century philosophy valuably diversified and contextualized justice more consistently than previous philosophies, yet without exploring the conceptual and political interconnectivity of facets of justice. A politically pernicious implication is that the face of justice (e.g. the social) ${ }^{8}$ that becomes discursively singled out and popularized monopolizes attention and appears to exhaust the meaning of justice or to cover the ground of other, less publicized distinctions of justice. Then, approaches to justice become responsive only to the glaring injustices that the discourse on the popularized face of justice has thematized as a case/ crisis where justice is applicable. Thus, less conspicuous injustices are overlooked.

\section{Distinctions of Justice}

The phrase "distinctions of justice" that I am using mines for illustrative purposes ${ }^{9}$ the rhetorical force of the ambiguity (semantic doubleness) of distinction: distinction signifies the quality of being special, different or excellent. But distinction also signifies a difference between two similar or related things. Here the first sense of distinction points to the exceptionality, excellence and special qualities of justice. The second sense relates to various faces of justice, to discernible conceptions or aspects of it. ${ }^{10}$ In other words, it refers to adjectival specifications of justice (e.g., social, environmental, transitional, global, reparative, epistemic, etc).

A distinction of justice in the qualitative sense of excellence is that the normativity of justice is unquestioned.

8 On this, see Papastephanou et.al, 2020.

9 Therefore, my discussion of the phrase "distinctions of justice" does not assume that this metaphorical use of the semantic behaviour of "distinction" (its homonymity in contexts of excellence and in contexts of differentiation) relates to the deep structure of the language of justice. By implication, my discussion merely mines the illustrative qualities of this homonymity and does not stand or fall on the translatability of the phrase "distinctions of justice" into other languages. That we need not use the word in English and that we need not be English speakers do not affect the rhetorical force of this ambiguity (in a text in English) to illustrate discursive operations that are otherwise too difficult to convey. Evidently, this ambiguity of "distinctions of justice" certainly does not affect the way in which agents (including people who do not make salient use of this English phrase) differentiate between different standards/conceptions/requirements of what, in their eyes, is just.

10 Distinctions of justice may also refer to how justice is distinguished from cognates and kindred notions, but this is beyond the scope of this article.
Stanley Fish states for a different purpose, en passant and in brackets an aphorism that, if thought through, is most revealing of the exceptionality of the concept of justice: "(No one declares himself to be an apostle of injustice)" (P. 43) [6]. He uses this aphorism to justify his remark ${ }^{11}$ on the ineffectiveness of appropriating claims to justice. But the aphorism also conveys something else, more telling of the exceptional, exalted status of justice (as a concept and in its self-standing face): though what counts as justice or injustice takes different contents, nobody programmatically defends the second pole of the "justice versus injustice" binarism; nobody questions, let alone denounces, the desirability of justice (qua concept, regardless of variations of meanings attributed to it by users); therefore, everybody seemingly or truly valorizes justice. ${ }^{12}$

The undisputed value attributed to justice also becomes evident when we realize that opting to put justice center stage rarely requires justification. Outside specialized disputes in meta-ethics and in some political-realist circles, we hardly feel like defending our choice of noun, let alone compelled to explain "why justice?" and "what is justice?"13 Certainly, the contents of justice, i.e., what counts as just, are considered debatable and deconstructible. ${ }^{14}$ However, justice as such, despite its terminological elusiveness, enjoys the discursive status of the normatively unchallenged. We may recall here that Jacques Derrida [7] transcendentalized this. He defended the impossibility yet necessity of justice, placing the deconstructibility of its manifestations alongside the non-deconstructibility of the concept. In this article, I do not go into what the transcendentalized exceptionality of justice means metaphysically and onto-anthropologically, but I confine my discussion to what this exceptionality entails (section 2) for political operations of adjectives attached to justice.

The notion of justice also enjoys a paramount unifying power and academic mobility in the human and socialsciences. Investigations of issues of justice constitute a common cause of (post-)analytic and continental philosophy, liberal and communitarian camps/perspectives and theoretical

11 "Invoking the abstract notions of justice and truth to support our cause wouldn't be effective anyway because our adversaries lay claim to the same language" (Fish, 2001, 43).

12 This valorization does not stand or fall on whether the person supposedly valuing justice merely pays lip service to it or capitalizes on the social value of the signifier "justice" or is even complicit in various injustices.

13 Even philosophers whose head-on engagement with these questions begins from common premises or traditions while taking opposite directions (e.g. compare the contractarian ethics of David Gauthier and John Rawls) still share the assumption of the desirability of justice despite their grounding it in different "whys" and "what".

14 It has to be noted that such deconstructions sometimes serve the worst complicities. 
and empirical research, despite the major differences in corresponding engagements with justice. Justice unites both sides of the "modern versus postmodern" divide, despite the fact that they are otherwise dissociated from one another. Critical social theory and various disciplines of applied social research also join forces in examining justice and in rendering it a key term of many projects and collaborative endeavors. Other nouns have failed to cross borders and to secure such convergence on them, since polemics of mindsets and persuasions often lead one camp/perspective to conceding a prominent noun ${ }^{15}$ to the opponents and to chastising them for normativizing it. Unlike such nouns, justice has survived polemics. As a border crosser par excellence, justice is always in transit from one discipline or persuasion to another.

The distinction of justice remaining normatively unchallenged is passed on to the modality of its differentiated uses, i.e., to its adjectival specifications (environmental, global, social, etc): distinctions of justice that specify claimants of justice (nature, animals, individuals, groups, practices, etc) simultaneously constitute vehicles for approximating something good. As the mobile concept of justice travels across thought (either alone or in the company of adjectival specifications) it is expected to: increase human mobility/mobilization; make subjects ethico-politically more mobile; move them towards creating a better world; and lead people to the good. However, "you cannot lead people to the good; you can only lead them to some place or other", wrote Ludwig Wittgenstein, ${ }^{16}$ probably to redeem the literal from the grip of the figurative and to stave off the bewitchment of philosophy by language. But, thought through, this aphorism reveals the non-circumventible metaphoricity ${ }^{17}$ of normativity. For, when people are literally led to places they are led to topoi that people see or experience as good or bad (utopias/dystopias). ${ }^{18}$ They visit or inhabit spaces invested

15 As a relevant example, consider that post-structuralism has conceded the notion of virtue to Anglo-American virtue epistemology. Poststructuralism does not revisit the notion of virtue. On the contrary, much recent communication with post-structuralist colleagues at conferences has helped me realize that they disparage all engagements with virtue as operating with downright moralistic assumptions of good and evil.

16 I am indebted to Professor Inga Bostad for drawing my attention to Wittgenstein's aphorism.

17 Here I employ this term in the Greek double sense of figure of speech and mobility, as metaphor denotes both the figurative and the transfer from one location to another.

18 Certainly, any binarism of "good-bad" and of "real or imagined" should be avoided here, since there are all sorts of mediations in between. But what is operative even in less extreme cases is a degree of normativization or de-normativation of a place or way of life, a degree of utopianization or dystopianization. Even when justice is reduced to a policy problem, the utopian question of the good place that is yet no place implicitly or explicitly informs the related discourse. Nowadays philosophy shies away less and less from acknowledging the utopian dimension in thinking of just policies (see, for instance, Gibson 2016). with or divested of normativity or desirability. Places can be real or imagined, turned nightmarish and uninhabitable or elevated to dreamworlds. This is the case not just in a blithe, quotidian sense, i.e., when people are led to crossing borders not by an actual force but by the promise suffusing a place and do so in thinking that they enact their own free choice. This is also the case in the literal, extreme and gruesome manner that, e.g., the Kurds of Syria ${ }^{19}$ were led to a different place, be it the place of the dead or various Western places, as they had to flee, to migrate in order to escape death. Political philosophers, social scientists and inactive global publics have, in their excitement for a post-Westphalian borderless world and in their sweeping indictment of just any claim to collective self-determination as supposedly nationalist, ${ }^{20}$ sleepwalked the way to this forced movement of a stateless people.

This brings us directly to the second sense of distinction, that of differentiating face $(\mathrm{t}) \mathrm{s}$ of justice. The distinct kind of justice relevant to what is owed to Kurds (condemned by $20^{\text {th }}$ century Western colonialism to a subaltern status in four countries) is the cosmopolitan; not just any cosmopolitan justice, but that which is sensitive to territorial, geopolitical intricacies and self-determination rights. Neither the "social" nor the "global" distinctions of justice can cover the province of international-right problems. Such problems are nowadays increasingly viewed in abstraction or obscured by the obsessive fascination with cities of refuge with no concern for those who stay in place and for what produces refugees in the first place. Wittgenstein's claim that "the good lies outside the space of facts" (P. 5) [8] receives a perfectly harrowing twist when we realize that in some cases the good lies precisely in the space of visibility and objective scrutiny of (often horrific, unbearable) facts. Such a space does justice to the "facts on the ground" that people facing an international problem experience in the world that they inhabit. Discursive justice to the politically uncomfortable knowledge that illuminates this space and cosmopolitangeopolitical justice are not reducible to social or global justice. Therefore, distinctions of justice that specify its practical relevance are absolutely necessary for justice to deal headon with neglected or obscured issues and, thus, to maintain, and merit, its distinguished status in the conceptual realm of most discourses.

\footnotetext{
19 Just indicatively: https://www.unocha.org/story/syria-un-remains-concerned-safetycivilians-north-east https://www.newsweek.com/turkey-accused-war-crimes-suspectedwhite-phosphorous-chemical-weapons-use-against-kurds-syria-1466248 https://www.theguardian.com/world/2019/oct/11/syria-turkey-conflictkurds-border-fighting-trump-deaths

20 For related references and textual corroboration, see Papastephanou, 2013a.
} 


\section{The Heuristic}

The proposed heuristic (see table below) concerns the use of adjectives for qualifying or specifying nouns. Depending on the degree of their normativization or denormativization exalted nouns are often qualified by adjectives. For instance, discontent with education has motivated educators to attach to it adjectives that evoke promise and hope for change: "transformative" education and "progressive" education are cases in point. But adjectives sometimes merely describe, specify and divide the conceptual labor of a noun. For example, "vocational" is the education that concerns workplace learning. A caveat here is that, certainly, the distinction of qualitative and descriptive adjectival operations is not neat. Though the adjective "vocational" describes a particular kind of education, in societies where the manual or technical is downplayed and the mental is privileged, the seemingly descriptive adjective bears qualitatively diminishing connotations. Still, despite its occasionally being blurred or, perhaps, precisely by being open to such a possibility, the distinction "descriptive - qualitative" increases awareness of what we do by using adjectives, of the politics of doing things with words. Further, another caveat, in fact a disclaimer, is needed before I proceed with the heuristic: I am not saying that the heuristic delivers desirable goods by itself. It is merely an epistemic tool that politicizes, and heightens consciousness of, how we talk about justice (and about other exalted nouns beyond the scope of this article). This heightening eases the passage to critiques of such talk and to considerations of a more stereoscopic outlook on justice. Indicatively:

\begin{tabular}{|c|c|c|c|}
\hline Ethico-Political Operations & Adjective & Noun & The Noun's Normative Status \\
\hline $\begin{array}{c}\text { Qualification } \\
\text { (disqualification) }\end{array}$ & $\begin{array}{c}\text { Critical, } \\
\text { New, } \\
\text { Vernacular, } \\
\text { Rooted, etc. } \\
\text { (old, cosmetic, etc). }\end{array}$ & Cosmopolitanism & $\begin{array}{l}\text { Uncertain/challenged } \\
\text { Normativity } \\
\text { Revisited Normativity }\end{array}$ \\
\hline Specification & $\begin{array}{c}\text { Social, } \\
\text { Global, } \\
\text { Political, } \\
\text { Environmental, } \\
\text { Discursive, } \\
\text { Epistemic, } \\
\text { Reparative, Distributive, } \\
\text { Legal, etc. } \\
\\
\text { (Biased, } \\
\text { Gendered, } \\
\text { Empty, } \\
\text { Unempathetic, etc. }\end{array}$ & 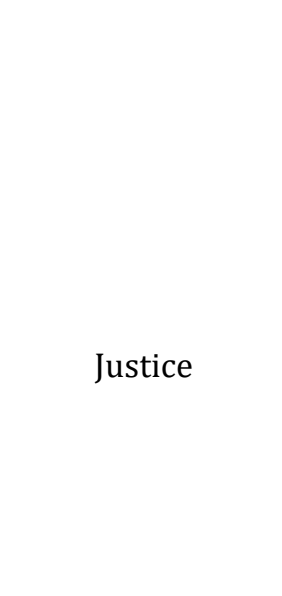 & $\begin{array}{l}\text { Unchallenged Normativity } \\
\text { Asserted } \\
\text { Normativity by Negation of } \\
\text { Degenerations }\end{array}$ \\
\hline
\end{tabular}

The following subsections (2.1. and 2.2.) explain the above table and flesh out the terms of the heuristic.

\section{The Adjectival Political Operation of Qualification (or Disqualification)}

The distinction (qua excellence) of the concept of justice is its undisputed normativity (against the disputed normativity of its various conceptions, applications and contextualizations). The implication is that justice receives no evaluative qualifiers ${ }^{21}$ and is not subjected to "adjectivenoun" operations of qualification. This gives rise to other adjectival operations specific to justice, as we will see in subsection 2.2.22 Since the exalted status of justice (its

21 When it does, it is only of its instantiations, i.e., gendered justice, biased, etc., as we will see later, and not of its inherent quality.

22 The case of adjectival determinations of injustice will not be explored here. Injustice is a different case, because it is, from an evaluative prism, an entirely negative concept (hence, it is neither of unchallenged nor of 
distinction qua excellence) protects justice from adjectival political operations of (dis)qualification, the present subsection (2.1.) illustrates (dis)qualifying operations through concepts (e.g. patriotism) whose normativity is questioned.

Patriotism is generally of disputed normative value today. To avoid undesirable undertones and to restore the normativity of this notion its proponents qualify it by using adjectives such as "critical", or adverbial-adjectival constructions such as "globally sensitive patriotism" [9]. Consider now a less challenged concept, cosmopolitanism, and a related "adjective-noun" political operation: that of "critical" or "new" cosmopolitanism. ${ }^{23}$ Cosmopolitanism is a largely positively meant noun. It functions normatively and its ideality is praised, desired and promoted. However, when criticisms of its bourgeois, elitist, abstract and Eurocentric features multiplied and obtained academic visibility and currency, adherents to cosmopolitanism felt obliged to concede to opponents that there is, indeed, a hegemonic, humanist (qua anthropocentric) cosmopolitanism that is open to such criticisms. ${ }^{24}$ To remain attached to cosmopolitanism and to maintain its normative function, its supporters had to keep distances from the tarnished conception of cosmopolitanism. They qualified their own cosmopolitanism by using adjectives such as "critical" or "new" and contrasted it to the "old cosmopolitanism". Theirs then is a cosmopolitanism that is sanitized, aware of risks, critical of its own pitfalls and original in its newly acquired wisdom and prudence.

The phrase "critical cosmopolitanism" consists of an adjective that qualifies and holds the noun "cosmopolitanism" in check; it thus allows cosmopolitan normativity to renew itself. The adjective preserves the noun's normative import and secures that its ideality remains uncontested or immune to well-rehearsed attacks. It helps cosmopolitanism maintain its political function as a regulative ideal, as a privileged academic notion of high impact factor and of numerous citations or downloads and as a key concept in the Western social imaginary. The adjectives "critical" and "new" define

partly challenged normative status). Engagement with its operations would sidetrack and needlessly lengthen the article.

23 To theorize this, I have drawn insights from D. A. Hollinger's (2001) article on cosmopolitanism. Despite our using a similar vocabulary concerning critical or new cosmopolitanism and the operation of holding cosmopolitanism in check through such adjectives, my approach departs from Hollinger's discussion in many ways.

24 Certainly, this account of the emergence of new or critical cosmopolitanism (which should not be used interchangeably, as I used them here for reasons of brevity and focus) is so brief that it cannot be other than reductive, perhaps even sweeping. Doing justice to the history of the conception of critical cosmopolitanism requires a genealogy that cannot be carried out here and has definitely far more complexity than any brief account could reflect. the "how" of approaching cosmopolitanism (in this case, by critically qualifying cosmopolitanism, by thinking it anew). Politically, this new or critical cosmopolitanism keeps away its disparaged, undesirable or pernicious older double, while continuing to perform, let us assume, cosmetic operations on a contemporary global society that sometimes seems beyond repair. Suppose that one considers as proof that this cosmopolitanism is cosmetic its verbal operations through which individuals engage with otherness in ways that secure their uplifted moral self-image. Individuals learn to talk in such a way that others cannot accuse them, say, of racism, but, beyond this personalized "cosmopolitan" task, too limited room is made for collective action. Eventually, individuals conveniently do too little toward material radical change of global conditions of life. They do not care enough about the other when the other is not a challenge within territory, nor do they worry about large scale destruction of the environment so long as this remains a governmental policy outside their scope. Individuals refrain from collective action so long as this requires deeper thought than sloganeering topics that have already attracted the public eye. One could accuse as cosmetic the persistently concentric cosmopolitanism that individualizes and privatizes global responsibility, and centralizes the self far more than Descartes could have ever expected (Papastephanou 2013b).

Let me self-reflectively draw the reader's attention to my use of the adjective "cosmetic". ${ }^{25}$ The adjective "cosmetic" accuses new cosmopolitanism of often paying lip service to the ideals and virtues that are typically associated with cosmopolitanism, instead of truly advancing them. Thus, it is employed to challenge critical or new cosmopolitanism and to point out what remains outside its vision. The adjective "cosmetic" that I attach to cosmopolitanism in fact illustrates the adjectival operation of disqualifying a specific conception of an exalted noun and of expressing dissatisfaction with how adjectives such as "new" or "critical" determine this noun. Discontent with existing determinants of an exalted noun (such as cosmopolitanism) invites new adjectives and reformulations of the noun's semantic contents. For instance, elsewhere (Papastephanou 2013b), I contrast to "concentric cosmopolitanism" an "ec-centric cosmopolitanism" that decenters the self. Sometimes, adjectival operations disqualify a certain delimitation of the scope of a noun in order to push critique further and press an alternative politics and alternative adjectival qualifications.

The adjectival operation that I have illustrated above with the case of "critical cosmopolitanism" is one of qualification of the noun. ${ }^{26}$ It simultaneously involves an

25 I modify and adapt the use of this term by Jan Nederveen Pieterse (2006).

26 Of course, this does not preclude that a noun of disputed normativity 
implicit disqualification of "old cosmopolitanism" and, possibly or potentially, of cosmopolitanisms alternative to the "new" /"critical" or of sibling rivals (e.g. "vernacular", "rooted", etc). Adjectival (dis)qualifications control the noun's conceptual elasticity: the noun should not denote inappropriate things; or the noun fails to meet its normative promise precisely by what the adjective accuses it of doing. ${ }^{27}$ To see how this operates vis-à-vis the adjectival modality of justice, i.e., the predicate "just", consider the example of just education. Such an operation is noticeable when two nouns, say, "justice" and "education" are put in an "adjective-noun" relationship, that is, when justice takes an adjectival form and the construction now becomes: just education. When the adjective "just" qualifies education, the latter is no longer "just" education in the sense of merely, simply education; that is, inter alia, it is not education merely for future profitmaking, seizing power, and becoming achiever. It is education as it should be, and this "should" is demarcated by whatever contents the "just" takes in the mind of the thinker/educator. Here the "just" indicates "how to rethink education" in an ethico-politically acceptable way. But when it comes to justice in its noun modality the question to which I will now turn is: how do adjectives that predicate justice operate?

\section{The Adjectival Political Operation of Specification}

I have singled out the adjectival operation of qualification, as it is illustrated through constructions such as "critical cosmopolitanism" and "just education". Yet, qualifying is not all that adjectives do to nouns. When the noun is of dubious normativity, adjectival qualifications are indeed most noticeable and frequent. But, as mentioned above, some nouns enjoy indisputable normative acceptance/ currency. Justice is one such noun. The widely accepted normative "distinction/excellence" of justice entails that the adjectives added to the noun "justice" do not qualify or hold its normativity in check; some concretize it or some operate protectively. ${ }^{28}$ In other words, philosophers do not add an adjective to inject a note of caution concerning a supposed inherent perniciousness of justice or to stave off criticisms that recruiting justice smacks of something bad.

Sometimes, it seems perfectly legitimate to employ

may not only be qualified but also specified, described through adjectives. For instance, cosmopolitanism may be described and have its scope narrowed down to kinds through adjectives without this necessarily entailing that this is done for qualification purposes. But, the figure, the scheme that I have provided, is merely indicative of how operations of qualification and specification may be illustrated; it does not aspire to be detailed, let alone exhaustive of the possibilities of determining a noun through adjectives.

27 As an example, consider again how I have used "cosmetic".

28 Such are cases where the ideal must be distinguished from bad/wrong instantiations, e.g. gendered justice, blind justice, etc. justice as a self-standing concept, in need of no specifications, as if making sense by itself. This is precisely how it is used in numerous titles of books, articles and research projects. Still, there are adjectives in discourses on justice and they do operate. They operate politically in ways that remain nontheorized and unexplored in philosophy and in research projects related to justice. When attached to justice, adjectives such as "social", "global", "discursive", "restorative", "distributive", etc., operate as differentiators of contexts or modes of applicability of justice. They narrow the scope of justice. They singularize spaces that invite justice and instantiate persons/groups having the right or the discursive power to occupy the position of the wronged, of the claimant, and possibly, of the recipient of justice. Or, adjectives such as "biased", "unempathetic", "gendered", etc., operate protectively, as the negative foil against which justice can assert itself. Such adjectives make the normative distinction of justice (its distance from bad instantiations or co-options) more visible.

Through adjectival specifications which make distinctions of justice and subjects/agents entitled to it visible, theory and research examine: cosmopolitan justice (see, e.g., Callegaro, and Marcucci [10]); multicultural justice (concerning rights of cultural groups); retributive justice (regarding punishment or blame); distributive justice (reshuffling of material sources on grounds of social priorities, individual need or desert); discursive justice (P. 43) [11]; transnational justice (P. 301) [12]; comparative and noncomparative justice ${ }^{29}$; reparative justice (P. 208) [13]; meta-political justice and reflexive justice [14]; military justice [15]; epistemic justice (P. 154) [16]; ${ }^{30}$ and transitional justice (P. 492) [17] ${ }^{31}$ - just to name a few indicatively.

To provide examples I have just placed some adjectives (that specify justice) in a linear order, in a parataxis, i.e., as a string of "adjective-noun" constructions. But this obscures the fact that they should be connected in a more complex association (in hypotaxis), which is what a stereoscopic vision could facilitate, as I argue later. It also obscures the politics beneath the complex reasons for which the above

\footnotetext{
29 "The basic principle of comparative justice is that like cases are to be treated alike and different cases to be treated differently"; "The basic principle of noncomparative justice is that each person should be treated according to his rights and deserts" (Hoffman, 1993, 165).

30 Epistemic injustice "occurs when prejudice on the part of the hearer leads to the speaker receiving less credibility than he or she deserves" (Fricker 2004, 154). I agree but I believe that epistemic injustice is far more than a matter of individual incredulity and discrediting of a speaker due to prejudice. Still, this is outside the confines of this article.

31 Transitional justice "is increasingly used to address the question of how emerging democracies should deal with past human rights abuses perpetrated or permitted by former authoritarian regimes" (Crocker, 1998, 492).
} 
succeed or fail to curve a niche in theory and research. Not all these predicates of justice have received even treatment. Not all of them have been met with discursive justice. Some stand out in having determined recent philosophical thinking about justice $^{32}$ sometimes, though not always, with good reasons. ${ }^{33}$ Interest in some adjectival specifications of justice and in the corresponding claimants of justice is not stable; it waxes and wanes, often depending on the ease with which a cause of justice can be turned communicable and translatable into a popularized vocabulary and into a linguistic structure that global publics and academia find attractive and accessible. However, sometimes, to theorize injustices for subordinated nature, people and topics you need a complex structure of subordinate clauses. This stretches linguistic limits and the capacity to accommodate subordinate clauses (hypotaxis) against a more digestible paratactic syntax of main clauses. It makes demands on the permeability of a lingua franca that is uncomfortable with "ugly", long words (of Greek or Latin origin). ${ }^{34}$ Intricacies of the various adjectives that determine justice require a more complex account of subordination and of unjust "facts on the ground" that are suffered by people who have, say, first-hand experiences of environmental destruction or of illegal political actions of other countries against their own territory.

Adjectival specifications of justice sometimes intersect. For example, reparative justice for climate refugees presupposes a complex interplay with environmental and cosmopolitan justice. Some countries (e.g. USA, China earlier) have, by not signing international agreements/ treaties on environment, had a lion's share of responsibility for the lack of environmental justice that has had refugee "effects on the ground" for some island populations. Treating

32 Consider, for instance, Rainer Forst's following apposite remark: "philosophical thinking about justice has developed along two very broad lines. One line focuses on the goods persons receive in a distributive scheme, comparing their share either with what relevant others have or with what persons need or deserve by some ethical standards, or both; the other line focuses on the relationship between the persons involved and their relative standing within a scheme of exercising power. One could call the first a focus on distributive justice, the latter one on political justice. The former is interested in the end-state of distributions and in the material well-being of persons, the latter in the legal and political standing of individuals (or groups) in an order claiming to be legitimate" (Forst, 2007, 260).

33 One good reason is that some specifications of justice, e.g., the distributive, are broad enough to cover vital ground from many perspectives, whilst other specifications are too narrow in scope and too specialized (e.g. military justice is limited to the institution of armies and to warfare or battlefield issues). Furthermore, a specification of, say, the military kind preserves its relevance so long as the institution and the corresponding practices that invite such justice are maintained. Hence, this specification is too particular to stand out and justifiably remains a side issue when seen from a broader scope, from a bigger picture. This, of course, does not diminish its significance within the confines that the adjective "military" specifies so long as there are armies in the world.

34 For a discussion of this issue, see (Papastephanou, 2015). justly such populations demands a synergy of historical, epistemic, environmental, re-distributive and reparative justice considerations that reflect a more cosmopolitan entanglement and liability than that of a reparative justice that chiefly concerns "within-state" recipients in the socalled "transitional" democracies.

The division of labor of specifications of justice that the heuristic has indicated simultaneously requires the synergy and complex relationship of these specifications into a whole; this points toward a qualifying operation: employments of justice either as self-standing (in need of no determinants) or as minimally differentiated should be reconsidered. For instance, much Critical Theory (especially of the second generation Frankfurt School thinkers such as Apel and Habermas) tends to employ justice as self-standing. Later generations of Frankfurt School thinkers or philosophers associated with this perspective tend to acknowledge, say, up to a "three-dimensional theory of justice" (P. 16) [14]; based on the above heuristic such standard tendencies should be revisited and qualified. More broadly, I qualify received views on justice (that either treat it as self-standing or exalt some of its facets and perspectives) by suggesting a "stereoscopic outlook on justice". My adjective "stereoscopic" operates both to qualify conceptions of justice and to specify/describe justice against limited, vague or too elastic alternatives. It does not qualify the normativity of the noun "justice" (justice as a concept). More specifically, it qualifies the vague conception of justice that operates either as self-standing or in the separate and disconnected use of each of its aspects or in assumptions of easy translatability (or reducibility) of one aspect into another.

\section{Stereoscopic Justice}

Thus: A stereoscopic justice is a multi-dimensional set of distinctions of justice that interact with and rely on one another. Their interconnectivity involves non-linear dynamics and difficulties (or, in some cases, the impossibility) of considering justice only through each of its distinctions. Viewing justice stereoscopically requires perception not just of the whole but also of its cracks. ${ }^{35}$ Why do we need a vision that allows this stereoscopic justice?

Even when the justice which is viewed as self-standing has the minimalist sense of freeing "social relations" from "the arbitrary rule of some over others" (P. 260) [18], the specific standpoint from which justice is tackled limits the scope of fitting examples of injustice. To explain this complex point: how we narrow justice down to specific instances determines the examples that we use for singling out claimants of justice. When justice is distributive, the issue (and

35 For a related analysis, see Papastephanou, 2021. 
corresponding examples) is who has and who has not. But, when the focus is on "political power", the issue is "how you are treated" (ibid), and focusing on this enables perception of injustices of, say, misrecognition or exclusion. Thus, within this focus, the deprived or the financially exploited may not be sufficiently visible to populate our spectrum of examples of potential recipients of justice. Likewise, I argue, if, say, a British or American philosopher/researcher limits her view of justice to uneven, lopsided social relations and unfair treatment of others in the corresponding social worlds, global injustices will be less visible to her. Examples of wronged people outside her social world, located elsewhere but harmed either by governmental policies of her country (e.g. the Chagossians wronged for decades by successive UK and USA governments) or by other states (e.g., the Syrian Kurds wronged by Turkey's invasion a while ago), will not become her own metonymies of injustice. ${ }^{36}$ Absorption by one predicate of justice confines "who counts" to those fitting well in the predicate's province. To avoid this we should not let one facet of justice cover the ground that a more fully-fledged, all-inclusive and stereoscopic justice (whose predicates operate in synergy and, possibly/occasionally, in tension) can cover.

To show that the province of one adjective is irreducible to the province of another let me briefly contrast social justice and geopolitically sensitive cosmopolitan justice. In most philosophy of justice nowadays, despite claims to the opposite, the underlying sensibilities are unwittingly expressions of methodological nationalism: they reflect political concerns of significance within territory, the country and the state. Transferred to the domain of reparative justice the scope of social justice makes reparations an issue of attention to victims of violations that occur domestically or are introterritorial in specific countries. ${ }^{37}$ The normative scheme of relevance is that of "policies furthering individual autonomy that are compatible with social justice and equality" (P. 208, emph mine) [13]. A geo-politically sensitive cosmopolitan justice, a more ec-centric cosmopolitan justice, in synergy

36 Nor will they fit in the "social relations" framework of the self-standing justice (see above quotation from Forst) and in the misrecognition/ exclusion framework that has now dominated preoccupations with justice by various disciplines.

37 Though there has been some literature that engages with inter-state and settler-colonial contexts (yet, again, not always utilizing principles of international justice), reparative justice seems to me to be increasingly confined to reparation measures for transitional, new democracies which have had a recent history of political violations or atrocities. In Ernesto Verdeja's words, "transitional democracies are nations emerging from a recent history of violence or authoritarian rule and moving in a broadly positive, liberal democratic normative direction. Reparations are understood as those policies and initiatives that attempt to restore to victims to their sense of dignity and moral worth and eliminate the social disparagement and economic marginalization that accompanied their targeting, with the goal of returning their status of citizens" (Verdeja, 2008, 208). with other facets of justice, is better qualified than social justice to cross the border that has been raised on reparative justice and has limited it either to transitional democracies or, within old democracies, to meeting refugee crises. It may make more visible and better accommodate those cases (e.g., Chagos, below) that cannot find justice within the political vocabulary of fashionable, normal academic discourses and of corresponding global public interventions [19-24].

The case of Chagos (Papastephanou, 2017b), the very requirement to explain it in every article and to provide its narrative because its events are unknown to post-Westphalian academics, this very expectation that I am deliberately resisting here, illustrates a paradox that I unpack below to strengthen the claim for stereoscopic justice. Let me prepare the ground for this by emphasizing that the other located not only outside our countries but also, and more importantly, outside our (post-)Westphalian mindscape (another sense of territoriality) usually remains unknown as a claimant of justice. The other sometimes becomes of political interest when she comes ashore, as a migrant "troubling" our conscience only by "troubling" our consolidated practices, our party politics, our public documents and policies. We know next to nothing about (or we quickly forget) the other when that other remains in place, dies there or is left to die in warfare and due to complex geopolitical-geostrategic and global hazards (e.g. Syrian Kurds). Most philosophers overlook challenges of global justice, international relations, and cosmopolitan right which concern claims to territory (e.g., Chagos), or claims to a kind of territorial justice against external threat (e.g., Kurds). For, such issues are already settled for most Northwestern countries and do not constitute challenges to one's daily life, nor do they stir collective memory nor do they effect the kind of countermemory that revives whatever still escapes Northwestern consciousness. The subject of actual, material injustice is also the subject of epistemic and discursive injustice.

The Westphalian mapping of responsibility is rightly criticized because, in its imagery, "the subjects of justice could only be fellow members of a territorialized citizenry" (P. 4) [14]. Some political space is still conceded to the territorial ${ }^{38}$ but, overall, current political theory maintains a self-understanding as post-Westphalian, as having denaturalized the territorial. It may have done so in words, as it has first theoretically impoverished the territorial by making it mean only intro-state, domestic affairs. But, in reality, despite its unquestionable feats, theory is still trapped in a paradox. I unpack it through the Chagos example as follows: justice to the people of Chagos is ill-fitting in the dominant

38 Even when some remaining significance is granted to territorial justice, this is done concerning the inward patriotism of transitional societies, issues of some redistribution within territory, etc. 
conception of social justice ${ }^{39}$ which deals either with introterritorial inclusion, mal-distribution, misrecognition and misrepresentation (in Northwestern countries) or with intro-territorial measures for making amends to oppressed minorities (in transitional democracies). Chagos mainly involves claims of return, claims of becoming a political community annexed to Mauritius, etc., that is, claims which are no longer academically attractive and do not easily pass through the usual scholarly gate-keeping. It concerns restoring the rights of return to people made refugees by two Western democracies for reasons of geo-political/strategic interests. Such reparative justice still remains outside the purview of an academia that is often more interested in a shallow peace or pax romana reconciliation. Also, many academics have lost interest in inter-state justice and in stateless people precisely because they endorse inter alia a post-Westphalian rhetoric the very moment that their work operates within methodologically nationalist logics of domestic, within-territory injustice. But, paradoxically, to dismiss the Westphalian wholesale is the royal route to remaining within its grip. For, instead of losing its hold, the theoretically impoverished Westphalian ${ }^{40}$ resurfaces in different guises precisely when, limited to intro-state relevance, it forfeits the counterfactual anti-imperial and anti-expansionist possibilities of rethinking the global that it comprised.

Subaltern populations and subaltern topics, themes that have not been done justice, e.g., self-determination and other such - now neglected - principles of justice, rupture current complacencies and fashionable political vocabularies, if read from a prism that complicates the (post-)Westphalian. They do so by revealing a plurality of distinct claims to justice and overlooked (sur)faces of justice, irreducible to the handful of slogans that impose a false unity on a world that is only seemingly experienced in company. Just as "some $\mathrm{S}$ is $\mathrm{P}$ " is a subaltern proposition to "all S is P", likewise the subaltern complicates the supposedly global "we" at which much political philosophy of the (presumably) "cosmopolitanized world" and much sociology of the "risk society" rejoice. We

39 The case of Chagos is also ill-fitting in the dominant conception of global justice that is crisis-dependent and responsive to what is globally current because the Chagos issue can be described as an ongoing crisis (for over 4 decades) only for the Chagossians, not for the rest of the world. It does not constitute a crisis in the eyes of non-Chagossians and, more, it has remained imperceptible by theories of global justice that possess the focus and tools only for dealing with globally visible crises and challenges. It also remains unnoticed by cosmopolitan theories that rely on an individualist globalism that does not sit well with territorial claims of collectivities.

40 Though the Westphalian as such did not include most of what has been attributed to it in late modernity regarding sovereignty, it has, indeed, been ever since used as shorthand for the basic principles underlying the modern state system. In this use, then, there is much more to it than non-interference of external forces in a territorially demarcated political configuration on grounds of a merely (and self-servingly) "domestic affairs" rationale. do not inhabit the same world. We do not face the same risks. ${ }^{41}$ As the Black Lives Matter philosophical ${ }^{42}$ mobilization (otherwise admirable and commendable) indirectly shows, black lives matter to theorists when these lives are within the country but not when they are elsewhere, though determined by the country's external policies; the black lives of the Chagossians have not mattered enough to ever mobilize philosophy.

A caveat here: that Chagos figures nowhere in research on justice other than in the technical regimes of courtroom justice (and the corresponding academic sources of legal justice) is certainly not just an issue of failures of postWestphalian Zeitgeist to be consistent, let alone to redeem counterfactual possibilities of the Westphalian. The ongoing academic blindness and quietude (predictable though no less disturbing for that matter) concerning Chagos ${ }^{43}$ cannot be totally explicable as a purely academic-discursive affair. A stereoscopic justice aims precisely to avoid such dematerializations of injustices by setting in motion a more complex process of diagnosing and critiquing realities. ${ }^{44}$ And another caveat: there is no doubt that whoever thinks about justice does so from an always situated perspective that allows insight into specific circumstances and focus on some distinctions of justice. We are not citizens of the same epistemic/affectiveworld.Hencemysuggestingastereoscopic justice does not entail that such a comprehensive view is either fully attainable or that it eliminates the particularity of fixed eyes or the significance of perspective. ${ }^{45}$ But it entails that the particularity of viewpoints and its reflection in diverse face(t)s of justice should be acknowledged. Furthermore, a synergy of specifications of justice neither rules out that they could be played off against one another, nor does it jettison the universalism that considers all people capable of justice and of crossing epistemic/affective borders.

Though contextualization has grounded many theorizations of justice, the interconnectivity step of analysis

41 Even risks such as the COVID-19, which are faced globally, are not faced by all places to the same degree and in the same way, since measures, infrastructures and means for dealing with an epidemic vary state-wise and affect strata of populations, classes and localities differently.

42 Consider here the many recent philosophical articles which engage with the corresponding movement and events and contrast it to the 4 decades absence of any reference to the Chagossian ordeals, the invisibility of Chagossians as claimants of justice, ever since the Chagos was emptied of people by US and UK policies.

43 Likewise, it partly explains the academic quietude concerning the Kurdish issue that is currently noticeable and, as we may predict with some certainty, will carry on after the dust of the recent events in Syria settles.

44 That is, a stereoscopic justice would not reduce the Chagos case to a merely "discursive justice" matter. It would mobilize other facets of justice to explore their synergy on the issue of Chagos at explanatory, justificatory and motivational levels.

45 On this, see Papastephanou, 2017b. 
that requires the complex relationality of a formal, general notion of justice and its specifications has not yet been taken. Therefore, a political benefit of the "stereoscopic" metaphor is that it provides this interplay of form and content. To explain it let me compare the "transitional" with the "stereoscopic". "Transitional justice" is conceptually very important in demarcating a normative inquiry appropriate to post-conflict or authoritarian transitions to democracy. ${ }^{46}$ It is more comprehensive than reparative, restorative or retributive face $(\mathrm{t}) \mathrm{s}$ of justice since it adds a context that is not captured by them. But it is nevertheless a specification of justice, rather than a formal "umbrella" term; it concretizes a setting, a specific surface of justice, as a topos of democratic deficits or of conflicts where temporality and the passage from one stage to another (transition) are crucial. As justice in times of political transition, it evokes a sense of crisis and problem-solving, that is, an already perceived, visible and acknowledged challenge of justice ${ }^{47}$ and those facets of justice that are relevant to it. By contrast, the designation "stereoscopic" has a formal character, since it encompasses all the differentiators of justice (each of which applies to a specific set of circumstances) regardless of whether there is a crisis that makes us aware of a face of justice or not. However, this does not mean that the stereoscopic lacks meaningful normativity and value. On the contrary, the very formalism of the stereoscopic provides a kind of zoomingout that, as I have indicated in my introduction, departs from reflective equilibrium tactics. It provides the necessary temporary abstraction and distancing from what the eye is accustomed to viewing as unjust. Its connotations of fuller vision as illustrated with the notion of interconnectivity invite a zooming-in as a constant reminder that one face of justice (e.g., the global) is not reducible to another (e.g. to the social and to its spheres of action such as education, migration, conflict-resolution, social policy, etc). That there is not only the social surface of the intro-state political affairs but also other (sur)faces, other spatialities which are geopolitically interconnected with one's own and claim justice could be obscured in single-focused efforts to contextualize justice. I hope that these clarifications of the benefits of the stereoscopic make more visible other benefits of it such as its exposing hierarchies of objects of justice that a perspectival

46 Thus, my comparison in this section does not aim to discard a perspective such as the transitional in favor of the "stereoscopic". It aims to demarcate its space as a very important specification of justice and of the synergy of distinctions of justice within transitional democracies. And it aims to show that the stereoscopic is more formal and broader than the transitional, since it extends well beyond specific spatialities in transition from authoritarianism to democracy or to a post-conflict state.

47 The "before" and "after" is certainly important also for the stereoscopic, because it is part of the very normativity of justice (qua passage from an unjust to a just order); but the stereoscopic shifts the emphasis from the temporal of transition to the visual and to the synchronic scope of political optics of justice. optic reproduces. ${ }^{48}$ But let me end this section by illustrating the difference between the transitional and the stereoscopic with the Chagos example.

Some issues of justice require awareness of the interconnectivity of distinctions such as the environmental, the cosmopolitan and the legal-international precisely there where the problem is not a matter of more democracy but of a more discerning eye and more global political sensibility. Thus, a case such as Chagos, for instance, which involves no transition (e.g. a supposedly missing democratization within the UK and the US that would facilitate justice to the Chagossians), nor is it globally popularized as a current crisis, escapes the "transitional justice" purview. The Chagossians are not located within either of the countries that have harmed them. ${ }^{49}$ Justice to them does not involve accommodation of them as migrants within UK or US territory; it involves visibility and then acknowledgement of their right to return to their land. The injustice that they suffered was followed by major environmental damage of their land and sea in the hands of the new "occupants" (Papastephanou 2017b). Concerning Chagos, by collecting images of justice (cosmopolitan, legal, political, reparative and environmental) together and making their intersection visible, the stereoscopic allows a fuller view of the interconnectivity of faces of justice and of surfaces of justice (different spatialities entangled in political effects on the ground). All these cannot be channeled into a "transitional democracy" framework also because they concern ongoing injustices that are conceptually irreducible to crisisdependent political idioms. Justice is not just a language game. Justice and injustice are realities experienced, lived out, sometimes outlived, sometimes lifelong cathectic. Engagements with justice are affective and motivated. The motivational ground of justice informs what counts as justice or which facet of it is viewed, singled out and extolled. Distinctions of justice also concern what (in)justice might be. Is justice a condition, a state of living, is it the governing principle of a prospective (or hoped for) topos? For Aristotle, and this has remained unacknowledged and neglected by contemporary philosophy, justice is a political virtue. To push this to its implications, consider the distinct territorial mark, sometimes indelible, that the absence of such a virtue leaves on earth surfaces, ecosystems, biota and nonbiota, landscapes, historical moments, societies, political configurations, institutions, families, writings, narratives and subjectivities. Stereoscopic justice comprises the foci and tools for dealing with this mark in complex and critical ways [25-31].

\footnotetext{
48 For more on such benefits, see Papastephanou, 2021.

49 The UK and the US uprooted them from their islands and marooned them to Mauritius and the Seychelles (see Papastephanou, 2017b).
} 


\section{Conclusion}

Justice, equality, democracy, cosmopolitanism, utopia, inclusion, respect, truth, and power are some nouns that are prominent in our political preoccupations, declarations and endeavors. Some of these nouns are central in our research today and stand out even in the titles of related scholarship. To introduce a stereoscopic approach to justice I have proposed a heuristic, a "quasi-analytics", of "adjective-noun" political operations that served critical and constructive purposes. I hope to have shown that this heuristic makes us more aware of linguistic operations that affect our political vision of justice.

Certainly, the metaphor "stereoscopic" serves illustrative purposes; thus it is not a basic element of justice in a conceptually essentialist sense. I have proposed it for its meta-philosophical political benefits. One of them is that it evokes focus, gaze, image, and (sur)face and a multi-focal potentiality of revealing the distant, the hitherto hidden from sight and the anamorphic eye that issues of overlooked justice require in order to become visible. Another related benefit is that "stereoscopy" provides to justice the much needed "technology" (figuratively meant) for capturing all viewing angles and retrieving the missing conceptual and political interconnectivity of (sur)faces of justice. The interconnectivity of (sur)faces of justice resembles inner projections of the stereoscopic visual structure (stereoscopic depth perception or illusion). Stereoscopic technology involves "functions that occur within the brain" when the mind "interprets what the eyes see" and estimates "the relative distances of objects from the viewer, and the depth dimension of those objects". ${ }^{50}$ It enables sighting sets of images that, outside the viewing apparatus, could have escaped the eye. Thus, metaphorizing justice as stereoscopic evokes a more "collective" vision of justice within scanned space and time.

\section{References}

1. Walzer M (1983) Spheres of Justice: a defense of pluralism and equality. New York: Basic Books.

2. Elster J (1992) Local justice: How institutions allocate scarce goods and necessary burdens. Russell Sage Foundation.

3. Lotman YM (2013) On the dynamics of culture. $\Sigma \eta \mu \varepsilon \imath \omega \tau \iota \kappa \eta$-Sign Systems Studies 41(2-3): 355-370.

4. Kelly MG (2018) For Foucault: Against Normative Political Theory. N. York: Suny Press.

50 https://en.wikipedia.org/wiki/Stereoscopy
5. Habermas J (1987) The Philosophical Discourse of Modernity. Lawrence F (Trans.). Cambridge: MIT.

6. Fish S (2001) Condemnation without absolutes. New York Times 15: 43-67.

7. Derrida J (1990) Force of Law: The 'Mystical Foundation of Authority,"' trans. Mary Quaintance. Cardozo Law Review 11(919): 230-298.

8. Wittgenstein L (1998) Culture and Value. von Wright GH, Nyman H, Pichler A (Trans.), Winch P (Ed.) Oxford: Blackwell.

9. Nussbaum MC (2008) Toward a Globally Sensitive Patriotism. Daedalus 137(3): 78-93.

10. Callegaro F, Marcucci N (2018) Europe as a political society: Emile Durkheim, the federalist principle and the ideal of a cosmopolitan justice. Constellations 25(4): 542-555.

11. Bunch M J (2014) Communicating for the purposes of human rights: Sex work and discursive justice in Canada. Can J Hum Rts 3: 39.

12. Schmalz D (2019) Social freedom in a global world: Axel Honneth's and Seyla Benhabib's reconsiderations of a Hegelian perspective on justice. Constellations 26(2): 301-317.

13. Verdeja E (2008) A critical theory of reparative justice. Constellations 15(2): 208-222.

14. Fraser N (2010) Scales of Justice: Reimagining Political Space in a Globalizing World. N. York: Columbia University Press.

15. Pieterse JN (2006) Emancipatory cosmopolitanism: Towards an agenda. Development and Change 37(6): 1247-1257.

16. Fricker M (2003) Epistemic justice and a role for virtue in the politics of knowing. Metaphilosophy 34(1-2): 154173.

17. Crocker D (1998) Transitional justice and international civil society: Toward a normative framework. Constellations 5(4): 492-517.

18. Forst R (2007) Radical Justice: On Iris Marion Young's Critique of the "Distributive Paradigm". Constellations 14(2): 260-265.

19. Buxton R (2019) Reparative Justice for Climate Refugees. Philosophy 94(2): 193-219.

20. García Gibson F (2016) Utopias and Comparative 
Assessments of Justice. Metaphilosophy 47(1): 92-107.

21. Habermas J, Derrida J, Borradori G (2003) Philosophy in a Time of Terror: Dialogues with Jürgen Habermas and Jacques Derrida. Chicago: University of Chicago Press.

22. Hoffman J (1993) A new theory of comparative and noncomparative justice. Philosophical studies 70(2): 165-183.

23. Hollinger DA (2001) Not Universalists, Not Pluralists: The New Cosmopolitans Find Their Own Way. Constellations 8(2): 236-248.

24. Rind M, Tillinghast $L$ (2008) What is an attributive adjective?. Philosophy 83(1): 77-88.

25. Papastephanou M (2021) And That's Not All: (Sur) Faces of Justice in Philosophy of Education. Philosophies 6(1): $1-16$.

26. Papastephanou M (2017a) Reflections on the European promise. New German Critique 44(2): 133-162.
27. Papastephanou M, Zembylas M, Bostad I, Oral SB, Drousioti K, et al. (2020) Philosophy of education in a new key: Education for justice now. Educational Philosophy and Theory.

28. Papastephanou M (2013a) Inward and outward patriotism. Review of European Studies 5(2): 20-32.

29. Papastephanou M (2013b) Being and Becoming Cosmopolitan: Higher Education and the Cosmopolitan Self. International Journal of Higher Education 2(2): 184-194.

30. Papastephanou M (2015) On ugliness in words, in politics, in tour-ism. Educational Philosophy and Theory 47(13-14): 1493-1515.

31. Papastephanou M (2017b) Patriotism and Pride beyond Richard Rorty and Martha Nussbaum. International Journal of Philosophical Studies 25(4): 484-503. 